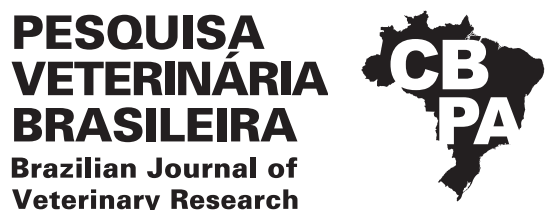

\title{
Meta-analysis of brucellosis vaccinology in natural hosts ${ }^{\mathbf{1}}$
}

\author{
Tatiane F. Carvalho ${ }^{2}$, João Paulo A. Haddad ${ }^{3}$, Tatiane A. Paixão ${ }^{4}$ \\ and Renato L. Santos ${ }^{2 *}$ (D)
}

\begin{abstract}
Carvalho T.F., Haddad J.P.A., Paixão, T.A. \& Santos R.L. 2020. Meta-analysis of brucellosis vaccinology in natural hosts. Pesquisa Veterinária Brasileira 40(8):604-613. Escola de Veterinária, Universidade Federal de Minas Gerais, Av. Pres. Antônio Carlos 6627, Pampulha, Belo Horizonte, MG 31270-901, Brazil. E-mail: rsantos@vet.ufmg.br

Brucellosis is a relevant zoonotic disease for which the most important tool for control is vaccination of susceptible animals. Assessment of vaccine efficacy in natural hosts is based on prevention of abortion and Brucella infection in organs of immunized animals. A metaanalysis of experimental vaccination of Brucella spp. natural hosts was performed, including 45 PubMed and/or Scopus-indexed publications, representing 116 individual experiments. Difference of risk was calculated as an indicator of protection, and a temporal analysis (19802016) demonstrated that experimental vaccines tested on natural hosts provided levels of protection that were stable over the past decades. The meta-regression model developed in this study included different vaccine categories (attenuated, inactivated, mutant, subunit, and vectored) considering the difference of risk as the dependent variable. The subcutaneous route of vaccination provided better protection when compared to the intramuscular and oral routes of vaccination. Surprisingly, inactivated vaccines provided better protection than live naturally attenuated vaccine strains (spontaneous mutations) that were considered the reference, whereas subunit vaccines provided lower levels of protection. This is the first meta-analysis of Brucella vaccinology in the natural hosts. These results are useful for the development of new vaccination protocols for controlling animal brucellosis.
\end{abstract}

INDEX TERMS: Meta-analysis, brucellosis, vaccinology, natural hosts, Brucella, vaccine, immunity.

RESUMO.- [Meta-análise da vacinologia de brucelose em hospedeiros naturais.] Brucelose é uma doença zoonótica relevante, para a qual a vacinação de animais susceptíveis é a ferramenta mais importante de controle. Avaliação da eficácia vacinal em hospedeiros naturais é baseada na prevenção de aborto e da colonização de órgãos pela Brucella spp. em animais imunizados. Foi realizada meta-análise de estudos de vacinação experimental de Brucella spp. em hospedeiros naturais, incluindo 45 publicações indexadas pela PubMed e/ou Scopus, representando 116 experimentos individuais.

\footnotetext{
${ }^{1}$ Received on April 22, 2020.

Accepted for publication on June 25, 2020.

${ }^{2}$ Departamento de Clínica e Cirurgia Veterinária, Escola de Veterinária, Universidade Federal de Minas Gerais (UFMG), Av. Pres. Antônio Carlos 6627, Pampulha, Belo Horizonte, MG 31270-901, Brazil. *Corresponding author: rsantos@vet.ufmg.br

${ }^{3}$ Departamento de Medicina Veterinária Preventiva, Escola de Veterinária, Universidade Federal de Minas Gerais (UFMG), Av. Pres. Antônio Carlos 6627, Pampulha, Belo Horizonte, MG 31270-901, Brazil.

${ }^{4}$ Departamento de Patologia Geral, Instituto de Ciências Biológicas, Universidade Federal de Minas Gerais (UFMG), Av. Pres. Antônio Carlos 6627, Pampulha, Belo Horizonte, MG 31270-901, Brazil.
}

Diferença de risco foi calculada como indicador de proteção e uma análise temporal (1980-2016) demonstrou que vacinas experimentais testadas em hospedeiros naturais promoveram níveis de proteção que foram estáveis ao longo das últimas décadas. 0 modelo de meta-regressão desenvolvido neste estudo incluiu diferentes categorias de vacinas (atenuada, inativada, mutante, subunidade e vetorial) considerando a diferença de risco como variável dependente. A via de vacinação subcutânea promoveu melhor proteção quando comparada às vias intramuscular e oral. Surpreendentemente, vacinas inativadas promoveram melhor proteção que vacinas vivas atenuadas (com mutações espontâneas) que foram consideradas como referência, enquanto vacinas de subunidades promoveram menor proteção. Este é o primeiro estudo de meta-análise da vacinologia de Brucella em hospedeiros naturais. Estes resultados são úteis para o desenvolvimento de novos protocolos vacinais para controle de brucelose animal. TERMOS DE INDEXAÇÃO: Meta-análise, vacinologia, brucelose, hospedeiros naturais, Brucella, vacina, imunidade. 


\section{INTRODUCTION}

Brucellosis is a highly relevant zoonotic disease worldwide caused by Gram-negative coccobacilli belonging to the genus Brucella (Pappas et al. 2005), which has very little genetic diversity and currently includes 12 species with particular host preferences, pathogenicity potential, and phenotypic features (Gándara et al. 2001, Al Dahouk et al. 2017). Classical Brucella species includes: B. melitensis, B. abortus, B. suis, $B$. canis, $B$. ovis, and $B$. neotomae. Human brucellosis is often associated with B. melitensis, B. abortus, or B. suis (Atluri et al. 2011), although there is an increasing number of reported cases of human brucellosis due to B. canis infection (Nomura et al. 2010, Marzetti et al. 2013).

Human infection occurs through ingestion, inhalation or contact mucosae or ulcerated skin with contaminated animal products. Occupational exposure is also a relevant risk while manipulating virulent strains in the laboratory or exposure to live attenuated vaccine strains (Young 1995, Godfroid et al. 2005, Corbel 2006, Atluri et al. 2011). The most common clinical manifestation of brucellosis in human patients is recurrent and persistent fever, but several complications may occur, including: osteomyelitis, arthritis, spondylitis, neurobrucellosis, and endocarditis (Gotuzzo et al. 1982, Rajapakse 1995, Pendela et al. 2017). Brucella spp. may also cause epididymitis and orchitis in man, and infect the placenta during pregnancy, although Brucella-induced abortion in pregnant woman is rare (Queipo-Ortuño et al. 2006).

In domestic animals, brucellosis is associated with infertility due to abortion in pregnant females or epididymitis and/ or orchitis in males (Anderson et al. 1986, Carvalho Neta et al. 2010, Poester et al. 2013), resulting in highly relevant economic losses for the animal industry (Santos et al. 2013). Official control programs in several counties are based on vaccination with live attenuated vaccine strains (Olsen \& Stoffregen 2005). Currently, the most common vaccine strains commercially available are B. abortus S19, B. abortus RB51, and B. melitensis Rev.1 (Cheville et al. 1993, Corbel 2006). Although very useful and protective, these vaccines have some disadvantages including residual pathogenicity since they may cause abortion in pregnant animals and may result in human infections (Schurig et al. 1991, Tobias et al. 1992, Elzer et al. 2002, Davis \& Elzer 2002). Furthermore, in the case of S19 e Rev.1, which has smooth LPS, there is interference with routinely used serologic tests (Cheville et al. 1992, Marín et al. 1999). Therefore, a large number of studies aiming to develop new vaccine protocols for brucellosis have been published in the past years. New vaccine technologies applied to brucellosis include subunit vaccines (Wyckoff et al. 2005, Estein etal. 2009), attenuated mutant strains (Kahl-McDonagh et al. 2006, Jacques et al. 2007, Fiorentino et al. 2008, Silva et al. 2015a, 2015b), and vectored vaccine protocols (Tabynov et al. 2014, Tabynov et al. 2016).

Complete eradication of brucellosis may not be achievable particularly due to wildlife reservoirs (Grégoire et al. 2012). Antibiotic treatment for human Brucella spp. infection is prolonged, expensive, and it is often followed by recurrence (Solera et al. 1998). Therefore, animal vaccination is the most important tool for controlling brucellosis in endemic areas (Corbel 2006), whereas there are no vaccines available for human use so controlling animal brucellosis is the most efficient approach for mitigating risks of human infections (Godfroid et al. 2005, Ko \& Splitter 2003, Ficht et al. 2009). The mouse has been extensively used as an animal model for brucellosis, particularly for vaccinology (Silva et al. 2011a). In a previous study, we analyzed all qualified experiments for Brucella vaccine development using the mouse model published over the past 30 years, which did not demonstrate clear progress towards the development of new vaccine protocols (Carvalho et al. 2016). This situation may reflect lack of potential of some experimental vaccine protocols, but also limitations of the mouse model. For instance, a B. ovis vaccine strain (Silva et al. 2011b) that provides moderate protection in the mouse model (Silva et al. 2015b) induces sterile immunity in its preferential host under experimental conditions (Silva et al. 2015a). Therefore, in this study we performed a comprehensive search of the literature to select all qualified experiments on Brucella spp. vaccine development using their natural preferential hosts, followed by the development of a meta-analysis model for identifying factors that may potentially improve vaccine efficacy in natural Brucella spp. hosts.

\section{MATERIALS AND METHODS}

Data source. Data was extracted from scientific articles indexed by Pubmed and Scopus until May 25, 2017. The following terms were used for literature search: "Brucella" and "vaccine". The list of publications was manually disambiguated, remaining only publications dealing with evaluation of vaccine protection of natural hosts after experimental challenge with pathogenic strains of Brucella spp. Criteria for inclusion of a given article was a clear statement of the number of experimental animals (immunized and non immunized) and the number of protected animals in each group, which allowed calculation of risk difference. All articles included in this study were written in English.

Meta-analysis was performed according to PRISMA (Preferred Reporting Items for Systematic Reviews and Meta-Analyses Criteria) ${ }^{5}$. Data from each experimental group were grouped according to the category of the experimental vaccine: (i) live naturally attenuated strains (from now on simply named attenuated); (ii) mutant attenuated strains (mutant); (iii) recombinant subunit vaccines (subunit); (iv) vectored vaccines (vector), and (v) inactivated vaccines (inactivated). Other parameters from each individual experiment that were considered in this analysis included: publication year, animal species, number of immunized and protected animals, immunization protocol (vaccination route, number of doses, and use of adjuvant), and parameters related to the experimental challenge (inoculation route, and Brucella species).

Protection of experimentally challenged males and females was based on prevention of abortion in pregnant females or prevention of infection of target organs.

Data transformation and meta-regression analysis. Data obtained from each article, including the following parameters: vaccine category, host species, use of adjuvant, Brucella species used for challenge, and challenge route, were evaluated to determine which parameters had influence on the risk difference. Original data were transformed into qualitative data, varying from 0 to 5 . Thus, values were attributed to these parameters as follows: vaccine category ("0" attenuated, "1" mutant, " 2 " subunit, "3" vector, or "4"

\footnotetext{
5 Available at $<$ http://www.prisma-statement.org/ $>$
} 
inactivated); host species ("0" cattle, "1" bison, “2" sheep, “3” goat, " 4 " deer, or " 5 " water buffalo); use of adjuvant (" 1 " yes, or " 2 " no); challenge Brucella species ("0"B. abortus, "1" B. melitensis, or "2" B. ovis); and rout of challenge ("0" conjunctival, "1" conjunctival and prepucial, " 2 " subcutaneous, or " 3 " intravenous).

The index of protected animals was obtained from the immunized and non immunized experimental groups from each article, which were named "protected vaccinated" and "protected control", respectively. Risk values were estimated based on the number of protected animals divided by the total number of animals in each experimental group. Risk difference was calculated subtracting the risk value of the vaccinated group from the risk value of the control group from each individual experiment. Risk difference varies from -1 to 1 . Therefore, risk difference was calculated according to the following formula:

Risk difference $(\mathrm{RD})=$ (number of protected vaccinated animals/ total number of vaccinated animals) - (number of protected non vaccinated animals/total number of non vaccinated animals)

A linear regression analysis was performed using the year of publication and risk difference as variables. Furthermore, the influence of each parameter (vaccine category, host species, and parameters related to immunization and challenge) on the value of risk.

Statistical analysis. A bivariate meta-regression analysis was performed using vaccine category as the dependent variable. Independent variables included: host species, vaccination route, use of adjuvant, number of doses, challenge route, and Brucella species used for challenge. Selection of variables for the multivariate metaregression analysis was based on a p value lower than 0.05 on the bivariate meta-regression. The Stata software (Statacorp, Texas, USA) was used for these analysis.

\section{RESULTS}

\section{Literature search and study characteristics}

This study included 45 articles with 116 individual experiments. Criteria for literature search and inclusion of articles are detailed on Figure 1.

\section{Vaccine protection of natural hosts over the past decades}

A correlation analysis between the year of publication of the experimental study and risk differences demonstrated that there was no statistically significant improvement of protection ( $p>0.05$ ) according to the risk differences over the past 36 years (Fig.2). Interestingly, there was a tendency for decreasing protection provided by experimental vaccines from 1980 to 2000 , whereas protection induced by experimental vaccines as indicated by risk difference tended to improve from 2000 to 2016 (Fig.2).

Figure 3 demonstrates trend lines for each individual experimental vaccine type, namely attenuated, mutant, subunit, vectored, and inactivated vaccines.

\section{Meta-analysis estimations}

Preliminarily, a bivariate meta-regression analysis was performed considering each of the variables controlled by vaccine category. Dependent variables included host species, route of vaccination, use of adjuvant, Brucella species, and route of challenge. From 1990 to 2000, considering attenuated vaccines as reference with a difference of risk of 0.4349 , subunit vaccines were significantly less protective with a difference of risk of $0.0258(\mathrm{p}<0.05)$, whereas difference of risk values for mutant and inactivated vaccines $(0.3673$ and 0.2401 , respectively) were statistically similar ( $p>0.05)$ to the difference of risk provided by naturally attenuated vaccine strains (Table 1). For meta-regression analysis of challenge route the conjunctival route was considered as reference with a difference of risk of 0.5770 , which was significantly higher than the subcutaneous route $(\mathrm{p}<0.05)$, which had a difference of risk equal to zero (Table 1 ).

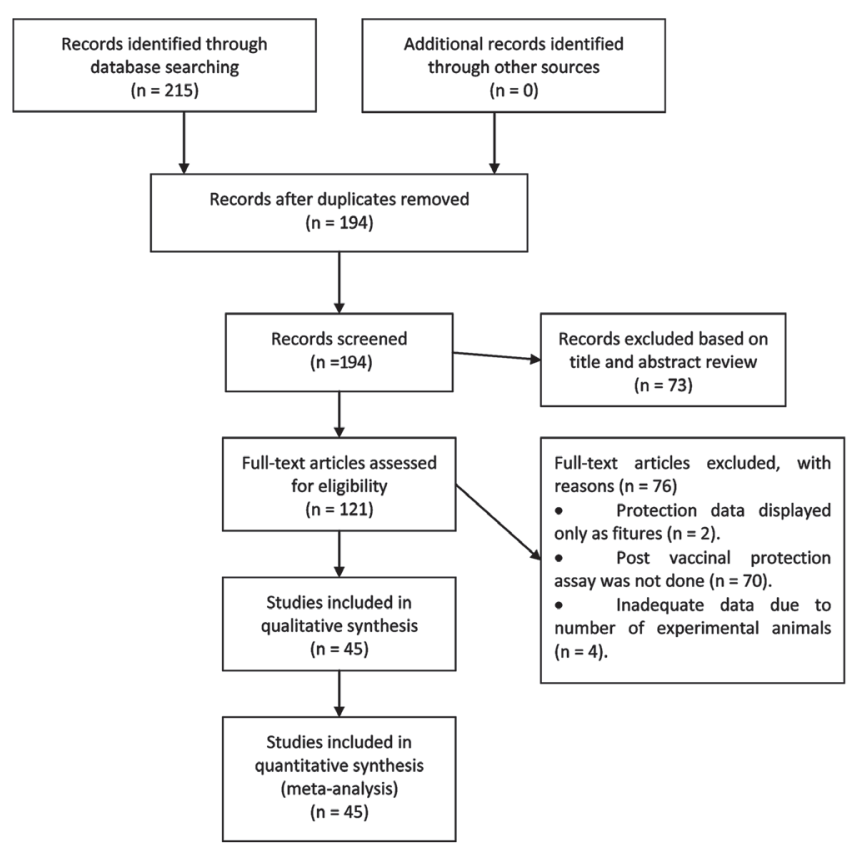

Fig.1. Flow chart describing the selection of articles from databases (Pubmed and Scopus) for inclusion in the meta-analysis, according to PRISMA (Preferred Reporting Items for Systematic Reviews and Meta-Analyses Criteria).

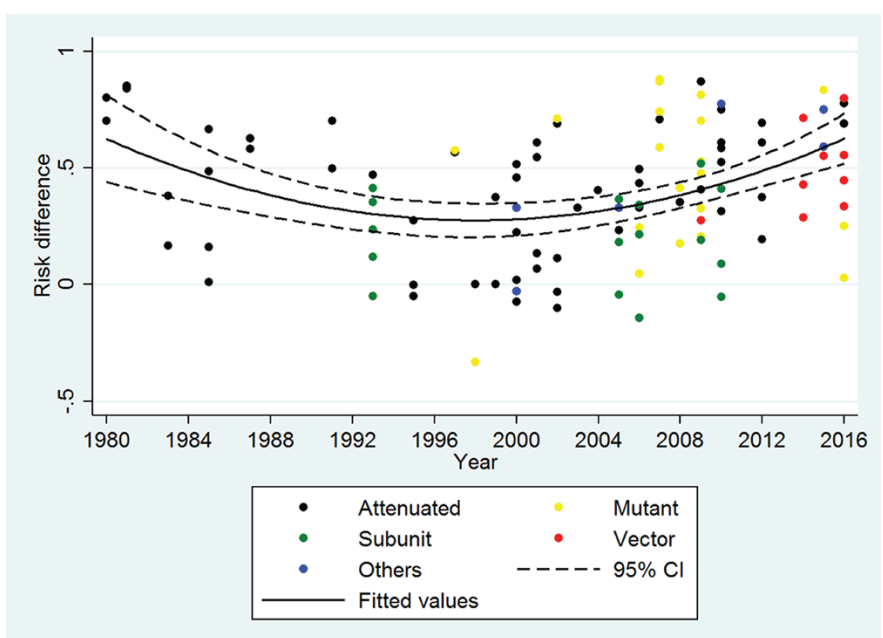

Fig.2. Linear regression analysis of risk of protection over time for different vaccines (attenuated, mutant, subunit, vectored, and inactivated) against Brucella spp. in their natural hosts. This analysis included 116 individual experiments with attenuated vaccines $(n=62)$, mutant vaccine strains $(n=23)$, subunit vaccines $(n=17)$, vectored vaccines $(n=9)$, and inactivated vaccines $(n=5)$ ( $\mathrm{r}=34.31, \mathrm{r} 2=11.77, \mathrm{p}=0.159)$. 
Protection provided by two immunizations (difference of risk $=0.5613)$ was statistically similar $(p>0.05)$ to a single immunization (difference of risk $=0.4533$ ) (Table 1). There were no statistically significant differences between host species, which included bison, sheep, goats, deer, and cattle (Table 1). Challenge with B. melitensis or B. ovis resulted in differences of risk of 0.2246 and 0.6269 , respectively, which were statistically similar to the difference of risk after challenge with B. abortus.
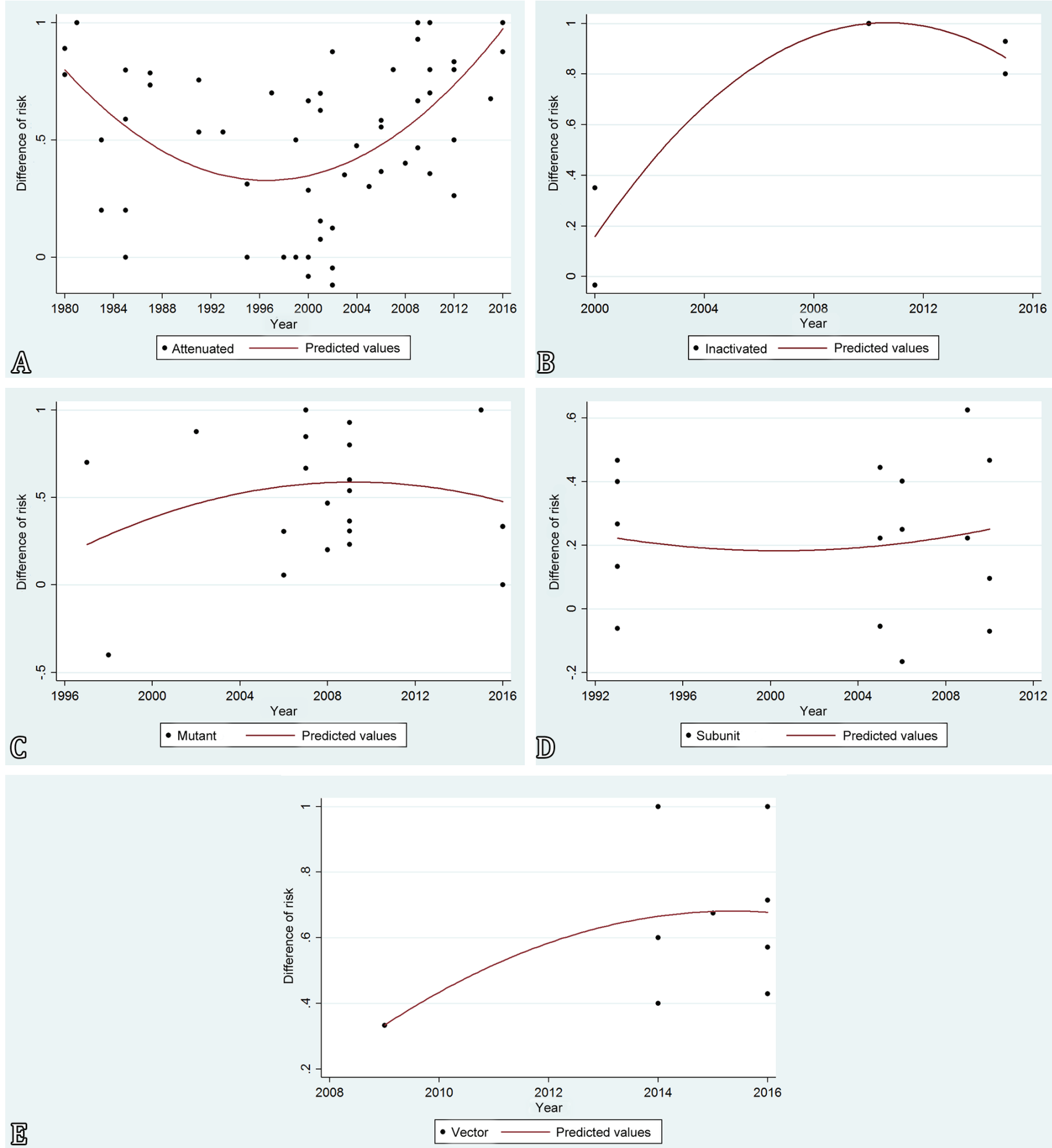

Fig.3. Linear regression analysis of risk of protection over time for each vaccine category against Brucella spp. in their natural hosts. (A) Naturally attenuated strains $(n=62),(B)$ inactivated vaccine $(n=5),(C)$ mutant vaccine strains $(n=23)$, (D) subunit vaccines ( $n=17)$, and (E) vectored vaccines $(\mathrm{n}=9)$. Each data point represents one individual experiment with a solid trend line. 
In the case of vaccination route, considering the occurrence of more than one route per experimental group, this variable was dichotomized prior to the analysis (Table 2).

Considering the period of 2000 to 2016 (Table 3), naturally attenuated vaccine strains with a difference of risk of 0.6320 performed significantly better that subunit vaccines (difference of risk $=0.169 ; \mathrm{p}<0.001$ ). Interestingly, the difference of risk provided by inactivated vaccines (1.005) was significantly higher than that provided by naturally attenuated vaccine strains $(\mathrm{p}<0.05)$ (Table 3$)$.

Regarding the host species, considering cattle as the reference (difference of risk $=0.6320$ ), bison, sheep, goat and water buffalos had differences of risk that were statistically similar. In contrast, deer had a statistically significant lower difference of risk (0.0701) when compared to cattle $(\mathrm{p}<0.0001)$ (Table 3$)$.

As pointed out above, since there were more than one vaccination route in a given experimental group, this variable was dichotomized prior to analysis. Both the intramuscular and oral vaccination routes were significantly protective (Table 4).
Two or three vaccine doses resulted in difference of risk values ( 0.4787 and 0.3965 , respectively) that were statistically similar to the difference of risk provided by a single vaccine dose (Table 3). The use of adjuvant did not have any statistically significant effect (Table 3).

Considering $B$. abortus as the reference challenge species (difference of risk $=0.4969$ ), B. melitensis and B. ovis resulted in higher differences of risk (0.6777 and 0.7041, respectively) when compared to $B$. abortus $(\mathrm{p}<0.05)$.

The subcutaneous route of challenge resulted in a significantly higher difference of risk (0.89) when compared to the conjunctival route (difference of risk $=0.5298$ ), which was considered the reference $(\mathrm{p}=0.01)$.

\section{Multivariate meta-regression}

The results of the bivariate meta-regression analysis were employed to select variables to be included in the multivariate meta-regression model. Therefore, the multivariate meta-

Table 1. Bivariate meta-regression analysis of variable that influenced difference of risk provided by brucellosis experimental vaccines from 1990 to 2000

\begin{tabular}{|c|c|c|c|c|}
\hline \multirow{2}{*}{ Variable } & \multirow{2}{*}{ Coefficient* } & \multirow{2}{*}{$P$ value } & \multicolumn{2}{|c|}{ Confidence intervals } \\
\hline & & & Lower limit & Upper limit \\
\hline \multicolumn{5}{|c|}{ Vaccine category - Reference: naturally attenuated - $p<0.001$} \\
\hline Mutant & -0.3673 & 0.912 & -0.7119 & 0.6384 \\
\hline Subunit & -0.4091 & $0.044^{* *}$ & -0.8056 & -0.0126 \\
\hline Inactivated & -0.2401 & 0.411 & -0.8273 & 0.3471 \\
\hline Constant & 0.4349 & $<0.001$ & 0.2619 & 0.6079 \\
\hline \multicolumn{5}{|c|}{ Number of doses - Reference: single vaccination $-\mathrm{p}<0.001$} \\
\hline Two doses & 0.1080 & 0.640 & -0.3571 & 0.5732 \\
\hline Constant & 0.4533 & $<0.001$ & 0.3055 & 0.6011 \\
\hline \multicolumn{5}{|c|}{ Host species - Reference cattle - $\mathrm{p}<0.001$} \\
\hline Bison & 0.2309 & 0.405 & -0.3278 & 0.7897 \\
\hline Sheep & 0.1292 & 0.427 & -0.1983 & 0.4569 \\
\hline Goats & -0.0513 & 0.860 & -0.6413 & 0.5386 \\
\hline Deer & -0.1287 & 0.750 & -0.9457 & 0.6884 \\
\hline Constant & 0.4143 & $<0.001$ & 0.2133 & 0.6154 \\
\hline \multicolumn{5}{|c|}{ Challenge species - Reference: Brucella abortus - $\mathrm{p}<0.001$} \\
\hline B. melitensis & -0.2103 & 0.346 & -0.6585 & 0.2379 \\
\hline B. ovis & 0.1920 & 0.221 & -0.1217 & 0.5058 \\
\hline Constant & 0.4349 & $<0.001$ & 0.2619 & 0.6079 \\
\hline \multicolumn{5}{|c|}{ Challenge route - Reference: conjunctival - $\mathrm{p}<0.001$} \\
\hline Conjunctival and prepucial & -0.3174 & 0.101 & -0.7007 & 0.0659 \\
\hline Subcutaneous & -0.6162 & $0.007^{* *}$ & -1.053 & -0.1794 \\
\hline Intravenous & -0.5769 & 0.058 & -1.1738 & 0.0199 \\
\hline Constant & 0.5770 & $<0.001$ & 0.4380 & 0.7158 \\
\hline
\end{tabular}

* Positive regression coefficients indicate that the variable have better protection than the reference when statistically significant. Negative coefficients indicate the opposite; ${ }^{* *}$ statistically significant differences $(\mathrm{p}<0.05)$.

Table 2. Dichotomized meta-regression analysis of the influenced route of vaccination on the difference of risk provided by brucellosis experimental vaccines from 1990 to 2000

\begin{tabular}{|c|c|c|c|c|}
\hline \multirow{2}{*}{ Vaccination route } & \multirow{2}{*}{ Coefficient* } & \multirow{2}{*}{$P$ value } & \multicolumn{2}{|c|}{ Confidence intervals } \\
\hline & & & Lower limit & Upper limit \\
\hline Subcutaneous & 0.1478 & 0.525 & -0.3204 & 0.6160 \\
\hline Constant & 0.3311 & 0.139 & -0.1133 & 0.7755 \\
\hline Intramuscular & -0.1846 & 0.636 & -0.9701 & 0.6008 \\
\hline Constant & 0.4703 & $<0.001$ & 0.3278 & 0.6129 \\
\hline
\end{tabular}


regression model included experiments published from 2000 to 2016, when there was a larger number of significant variables according to the bivariate meta-regression. The multivariate meta-regression model included the following vaccine categories: naturally attenuated vaccine strains, mutant vaccine strains, subunit vaccines, vectored vaccines, and inactivated vaccines, considering the difference of risk as the dependent variable and the other variables (vaccination route and challenge route) as independent variables (Table 5).

Subunit vaccines provided lower protection when compared to naturally attenuated vaccines $(\mathrm{p}=0.002)$, which was considered the reference. Conversely, inactivated vaccines

Table 3. Bivariate meta-regression analysis of variable that influenced difference of risk provided by brucellosis experimental vaccines from 1990 to 2000

\begin{tabular}{|c|c|c|c|c|}
\hline \multirow{2}{*}{ Variable } & \multirow{2}{*}{ Coefficient* } & \multirow{2}{*}{$P$ value } & \multicolumn{2}{|c|}{ Confidence interval } \\
\hline & & & Lower limit & Upper limit \\
\hline \multicolumn{5}{|c|}{ Vaccine category - Reference: naturally attenuated - $p<0.001$} \\
\hline Mutant & 0.0076 & 0.922 & -0.1481 & 0.1634 \\
\hline Subunit & -0.4630 & $<0.001^{* *}$ & -0.6678 & -0.2583 \\
\hline Vectored & 0.0616 & 0.588 & -0.1645 & 0.2878 \\
\hline Inactivated & 0.3733 & $0.029 * *$ & 0.0390 & 0.7076 \\
\hline Constant & 0.6320 & $<0.001$ & 0.4714 & 0.7927 \\
\hline \multicolumn{5}{|c|}{ Host species Reference: cattle $-\mathrm{p}<0.001$} \\
\hline Bison & -0.1324 & 0.314 & -0.3927 & 0.1278 \\
\hline Sheep & 0.6390 & 0.474 & -0.1131 & 0.2409 \\
\hline Goat & 0.0017 & 0.989 & -0.2452 & 0.2487 \\
\hline Deer & -0.5619 & $0.001^{* *}$ & -0.8286 & -0.2951 \\
\hline Water buffalo & 0.2909 & 0.148 & -0.1058 & 0.6876 \\
\hline Constant & 0.6320 & $<0.001$ & 0.4714 & 0.7927 \\
\hline \multicolumn{5}{|c|}{ Number of doses - Reference: single vaccination $-\mathrm{p}<0.001$} \\
\hline Two doses & -0.1310 & 0.293 & -0.3775 & 0.1155 \\
\hline Three doses & 0.2132 & 0.410 & -0.2995 & 0.7259 \\
\hline Constant & 0.6097 & $<0.001$ & 0.4980 & 0.7215 \\
\hline \multicolumn{5}{|c|}{ Adjuvant - Reference: without adjuvant - $\mathrm{p}<0.001$} \\
\hline With adjuvant & 0.0818 & 0.562 & -0.1983 & 0.3618 \\
\hline Constant & 0.5978 & $<0.001$ & 0.4871 & 0.7086 \\
\hline \multicolumn{5}{|c|}{ Challenge species - Reference: Brucella abortus - $\mathrm{p}<0.001$} \\
\hline B. melitensis & 0.1808 & $0.039 * *$ & 0.0091 & 0.3527 \\
\hline B. ovis & 0.2072 & 0.055 & -0.0043 & 0.4188 \\
\hline Constant & 0.4969 & $<0.001$ & 0.3592 & 0.6346 \\
\hline \multicolumn{5}{|c|}{ Challenge route - Reference: conjunctival - $\mathrm{p}<0.001$} \\
\hline Conjunctival and prepucial & 0.1274 & 0.199 & -0.0688 & 0.3235 \\
\hline Subcutaneous & 0.3602 & $0.010^{* *}$ & 0.0893 & 0.6312 \\
\hline Constant & 0.5298 & $<0.001$ & 0.4094 & 0.6501 \\
\hline
\end{tabular}

* Positive regression coefficients indicate that the variable has better protection than the reference when statistically significant. Negative coefficients indicate the opposite; ${ }^{* *}$ statistically significant differences $(\mathrm{p}<0.05)$.

Table 4. Dichotomized meta-regression analysis of the influenced route of vaccination on the difference of risk provided by brucellosis experimental vaccines from 1990 to 2000

\begin{tabular}{|c|c|c|c|c|}
\hline \multirow{2}{*}{ Vaccination route } & \multirow{2}{*}{ Coefficient* } & \multirow{2}{*}{ P value } & \multicolumn{2}{|c|}{ Confidence intervals } \\
\hline & & & Lower limit & Upper limit \\
\hline Subcutaneous & 0.0995 & 0.224 & -0.0623 & 0.2614 \\
\hline Constant & 0.5281 & $<0.001$ & 0.3699 & 0.6862 \\
\hline Conjunctival & 0.2011 & 0.054 & -0.0039 & 0.4060 \\
\hline Constant & 0.5732 & $<0.001$ & 0.4618 & 0.6847 \\
\hline Intramuscular & -0.2916 & $0.009 *$ & -0.5095 & -0.0737 \\
\hline Constant & 0.6488 & $<0.001$ & 0.5373 & 0.7603 \\
\hline Oral & -0.5136 & $0.025^{* *}$ & -0.9618 & -0.0654 \\
\hline Constant & 0.5994 & - & 0.4929 & 0.7059 \\
\hline Intradermic & 0.0022 & 0.995 & -0.7494 & 0.7538 \\
\hline Constant & 0.5978 & $<0.001$ & 0.4870 & 0.7086 \\
\hline
\end{tabular}


provided significantly better protection as indicated by the difference of risk when compared to the reference $(p=0.007)$.

Regarding the vaccination routes, the subcutaneous route provided better protection than intramuscular and oral routes $(\mathrm{p}<0.05)$.

Experimental vaccines resulted in better protection when the challenge was performed by the subcutaneous route when compared to the conjunctival route $(p=0.016)$, which was considered the reference.

\section{DISCUSSION}

Brucellosis is one of the most important zoonotic diseases worldwide. Importantly, the incidence of human brucellosis is strongly related to the prevalence in domestic animals (Gomez et al. 2013). Currently, vaccination is the most important tool for controlling infection and disease in animals, although vaccination alone is not sufficient for eradication of brucellosis (Corbel 2006, Grégoire et al. 2012). Therefore, there is still an enormous research effort for developing better and safer vaccines against Brucella (Saez et al. 2012, Curina et al. 2018, Paul et al. 2018). In this study we performed a meta-analysis that included a large series of experiments assessing protection against Brucella spp. in their natural host species. Meta-analyses of studies on the natural host is quite challenging since it requires comparisons among different host species, diagnostic methods, and parameters of protection, such as prevention of abortion, decrease of bacterial loads in tissues, prevention of lesions, among other parameters. In contrast, in the mouse model, in spite of variable experimental designs, the outcome is the same, which is protection index calculated based on the differences of bacterial loads in the spleen of vaccinated and non vaccinated mice (Carvalho et al. 2016). Therefore, our study was based on risk difference, which allowed comparison of original studies that employed different diagnostic methods to measure different outcomes of infection. This approach allowed us to compare traditional vaccines, including commercially available vaccine strains, with several different experimental vaccine protocols. A correlation analysis of year of publication and vaccine protection as predicted by the difference of risk indicated that protection provided by different types of experimental vaccines has remained stable over the past almost four decades. This finding is similar to our previous study in which a temporal analysis of protection induced by experimental Brucella vaccines in mice indicating stable protection indexes over the past three decades (Carvalho et al. 2016). Therefore, additional research efforts are needed for the development of the ideal Brucella vaccine, which may prevent infection and disease without adverse effects due to residual pathogenic potential for animal and humans (Dorneles et al. 2015, Xie et al. 2018).

To the best of our knowledge this is the first meta-analysis study of Brucella vaccinology in natural hosts. Our previous meta-analysis study was based on the mouse model (Carvalho et al. 2016), which is highly relevant since the mouse has been extensively used as a model for studies on pathogenesis, immune response and vaccine protection (Baldwin \& Parent 2002, Silva et al. 2011a). Furthermore, the mouse is a convenient and inexpensive experimental model (Perkins et al. 2010). However, in spite of intensive Brucella vaccine research in this model, it is not clear how efficient is the mouse to predict protection in the different natural host species (Dorneles et al. 2015). For instance, in our experience an experimental vaccine with only moderate protection in the mouse (Silva et al. 2015b) induced sterile immunity in the natural host (Silva et al. 2015a). Experimental assessment of vaccine efficacy in natural hosts is therefore preferable, but experiments with pregnant cows for example are extremely expensive and require large animal biosafety level 3 facilities (Dorneles et al. 2015). In spite of these limitations, experimental assessment of vaccine protection is well established and highly relevant (Olsen et al. 1999, Poester et al. 2006). However, experimental assessment of vaccines in natural hosts may be influenced by several factors that do not affect the mouse model, including nutritional and immunological status, age, and environmental stress (Olsen et al. 2015).

Surprisingly, in spite of the dogma in the field of Brucella vaccinology that live attenuated vaccines are required for appropriate levels of protection, this study demonstrated that experimental vaccine formulations based on inactivated

Table 5. Multivariate meta-regression analysis of variables influencing the difference of risk provided by experimental brucellosis vaccines in natural hosts from 2000 to 2016

\begin{tabular}{|c|c|c|c|c|c|}
\hline \multirow{2}{*}{ Variable } & \multirow{2}{*}{ Coefficient* } & \multirow{2}{*}{ Standard error } & \multirow{2}{*}{$P$ value } & \multicolumn{2}{|c|}{ Confidence interval } \\
\hline & & & & Upper limit & Lower limit \\
\hline \multicolumn{6}{|c|}{ Vaccine category - Reference: naturally attenuated - $p<0.001$} \\
\hline Mutant & 0.0839 & 0.0905 & 0.357 & -0.0968 & 0.2646 \\
\hline Subunit & -0.3979 & 0.1206 & $0.002^{* *}$ & -0.6387 & -0.1572 \\
\hline Vectored & -0.1885 & 0.1446 & 0.197 & -0.4772 & 0.1001 \\
\hline Inactivated & 0.4742 & 0.1714 & $0.007^{* *}$ & 0.1319 & 0.8164 \\
\hline \multicolumn{6}{|c|}{ Vaccination route - Reference: subcutaneous - $\mathrm{p}<0.001$} \\
\hline Intramuscular & -0.2232 & 0.1064 & $0.040^{* *}$ & -0.4356 & -0.0106 \\
\hline Oral & -0.4547 & 0.2138 & $0.037^{* *}$ & -0.8817 & -0.0277 \\
\hline \multicolumn{6}{|c|}{ Challenge route - Reference: conjunctival - $\mathrm{p}<0.001$} \\
\hline Conjunctival and prepucial & 0.0666 & 0.093 & 0.477 & -0.1191 & 0.2524 \\
\hline Subcutaneous & 0.3139 & 0.1274 & $0.016^{* *}$ & 0.0595 & 0.5682 \\
\hline Constant & 0.5861 & 0.0607 & $<0.001$ & 0.4650 & 0.7073 \\
\hline
\end{tabular}

* Positive regression coefficients indicate that the variable has better protection than the reference when statistically significant. Negative coefficients indicate the opposite; ${ }^{* *}$ statistically significant differences $(\mathrm{p}<0.05)$. 
Brucella provided significantly higher protection as evidenced by their difference of risk when compared to naturally attenuated vaccine strains. A possible drawback of these inactivated vaccine formulations is long term immunity, which may justify the fact that the broadly used Brucella vaccines are live attenuated strains including $B$. abortus $\mathrm{S} 19$, B. abortus RB51, and B. melitensis Rev.1 (Cheville et al. 1993, Olsen \& Stoffregen 2005, Corbel 2006). These strains promote good levels of long lasting protection and they are associated with a cellular immune response (Seder \& Hill 2000, Titball 2008), which is required for controlling Brucella infection (Baldwin \& Goenka 2006). Therefore, our meta-analysis data must be interpreted with caution since it does not assess long term immunity as most studies included in this analysis evaluated short term protection.

Together, the studies on inactivated vaccines included in this meta-analysis indicate that inactivated vaccines are capable of reducing incidence of infection in maternal and fetal tissues as well as preventing abortion in pregnant females. Olsen et al. (2015) demonstrated that an inactivated Brucella vaccine provided superior protection when two doses were administered with one year interval, resulting in reduction of the number of abortions when compared to non vaccinated bison or those vaccinated with a single dose. Development of inactivated Brucella vaccines are promising since in spite of good levels of protection, live attenuated vaccines retain virulence and are capable of causing abortion in vaccinated pregnant females. Live attenuated vaccines also often interfere with routinely used serologic tests. Furthermore, the Rev.1 vaccine strain is not allowed in areas free of B. melitensis (Cheville et al. 1992, Schurig et al. 2002, Vemulapalli et al. 2002, Dorneles et al. 2015). Furthermore, live attenuated strains are not applicable to humans since they have residual virulence, and can potentially cause human infection and disease (Waag et al. 2002, Rockx-Brouwer et al. 2012). Conversely, inactivated vaccines have desirable features for an ideal vaccine since it does not cause disease or infection in vaccinated animals, preventing any possibility of vaccine-induced abortion (Schurig et al. 1995, Ko \& Splitter 2003). A vaccine is considered effective when it is capable of preventing development of the disease or minimizes risk of infection in vaccinated animals (Grilló et al. 2009). Therefore, the difference of risk is related to protection evidenced by reduction in abortion rates, generation of weak newborns, and decrease in bacterial loads in vaccinated animals (Elzer et al. 1998, Nol et al. 2016).

This study also demonstrated that subunit vaccines are less protective than naturally attenuated vaccine strains. Development of protective Brucella subunit vaccines is very challenging due to the difficulty to identify immunogenic and protective antigens, and the low probability of induction of protective immunity dependent on a single antigen (Titball 2008, Plotkin 2010, Yang et al. 2013). Subunit vaccines have also proven less protective in the mouse model (Carvalho et al. 2016), although some individual studies resulted in promising results, which may not correlate with protection in natural hosts (Dorneles et al. 2015).

Routes of vaccination and challenge influenced protection in natural host species under experimental conditions. This study demonstrated that the subcutaneous route of vaccination provides better results, which is in good agreement with previous reports (Marín et al. 1990, Todd et al. 2013, Carvalho et al. 2016). Importantly, the subcutaneous route is recommended for commercially available Brucella vaccines including S19, RB51, and Rev.1 (Beckett \& Macdiarmid 1985, Xie et al. 2018).

\section{CONCLUSION}

Spite of new technologies for vaccine development, additional studies are needed to improve Brucella vaccine development since protection remained stable over the past decades. Interestingly, inactivated vaccine formulations demonstrated better protection, suggesting that this approach should be considered for future studies in the field of Brucella vaccinology.

Acknowledgements.- Work in R.L.S. lab is supported by "Conselho Nacional de Desenvolvimento Científico e Tecnológico" (CNPq), Brazil, "Fundação de Amparo a Pesquisa do Estado de Minas Gerais" (FAPEMIG), Brazil, and "Coordenação de Aperfeiçoamento de Pessoal de Nível Superior" (CAPES), Brazil. R.L.S., T.A.P. and J.P.A.H. have fellowships from CNPq. The funders had no role in study design, data collection and analysis, decision to publish, or preparation of the manuscript.

Conflict of interest statement.- There are no conflicts of interest.

\section{REFERENCES}

Al Dahouk S., Köhler S., Occhialini A., Jiménez de Bagüés M.P., Hammerl J.A. Eisenberg T., Vergnaud G., Cloeckaert A., Zygmunt M.S., Whatmore A.M., Melzer F., Drees K.P., Foster J.T., Wattam A.R. \& Scholz H.C. 2017. Brucella spp. of amphibians comprise genomically diverse motile strains competent for replication in macrophages and survival in mammalian hosts. Sci. Rep. 7:44420. <https://dx.doi.org/10.1038/srep44420><PMid:28300153>

Anderson T.D., Meador V.P. \& Cheville N.F. 1986. Pathogenesis of placentitis in the goat inoculated with Brucella abortus. I. Gross and histologic lesions. Vet. Pathol. 23(3):219-226. <https://dx.doi.org/10.1177/030098588602300301> <PMid:3088809>

Atluri V.L., Xavier M.N., de Jong M.F., den Hartigh A.B. \& Tsolis R.M. 2011 Interactions of the human pathogenic Brucella species with their hosts. Annu. Rev. Microbiol. 65:523-541. <https://dx.doi.org/10.1146/annurevmicro-090110-102905> <PMid:21939378>

Baldwin C.L. \& Goenka R. 2006. Host immune responses to the intracellular bacteria Brucella: does the bacteria instruct the host to facilitate chronic infection? Crit. Rev. Immunol. 26(5):407-442. <https://dx.doi.org/10.1615/ critrevimmunol.v26.i5.30> <PMid:17341186>

Baldwin C.L. \& Parent M. 2002. Fundamentals of host immune response against Brucella abortus: what the mouse model has revealed about control of infection. Vet. Microbiol. 90(1/4):367-382. <https://dx.doi.org/10.1016/ s0378-1135(02)00222-5> <PMid:12414157>

Beckett F.W. \& Macdiarmid S.C. 1985. The effect of reduced-dose Brucella abortus strain 19 vaccination in acredited dairy herds. Brit. Vet. J. 141(5):507-514. <https://dx.doi.org/10.1016/0007-1935(85)90046-6><PMid:4063777>

Carvalho Neta A.V., Mol J.P.S., Xavier M.N., Paixão T.A., Lage A.P. \& Santos R.L. 2010. Pathogenesis of bovine brucellosis. Vet. J. 184(2):146-155. <https:// dx.doi.org/10.1016/j.tvjl.2009.04.010> <PMid:19733101>

Carvalho T.F., Haddad J.P.A., Paixão T.A. \& Santos R.L. 2016. Meta-Analysis and advancement of brucellosis vaccinology. PLoS One 11(11):e0166582. <https://dx.doi.org/10.1371/journal.pone.0166582> <PMid:27846274>

Cheville N.F., Jensen S.M., Halling F.M., Tatum F.M., Morfitt D.C., Hennager S.G., Frerichs W.M. \& Schurig G. 1992. Bacterial survival, lymph node changes, and immunologic responses of cattle vaccinated with standard and mutant strains of Brucella abortus. Am. J. Vet. Res. 53(10):1881-1888 <PMid:1456536> 
Cheville N.F., Stevens M.G., Jensen A.E., Tatum F.M. \& Halling S.M. 1993. Immune responses and protection against infection and abortion in cattle experimentally vaccinated with mutant strains of Brucella abortus. Am. J. Vet. Res. 54(10):1591-1597. <PMid:8250382>

Corbel M.J. 2006. Brucellosis in humans and animals. Food and Agriculture Organization of the United Nations, World Health Organization, Geneva. 89p.

Curina G., Nardini R., Corneli S., D’Avino N., Tentellini M., Montagnoli C., Severi G., Forti K., Paternesi B., Coletti M. \& Cagiola M. 2018. Evaluation of immune responses in mice and sheep inoculated with a live attenuated Brucella melitensis REV1 vaccine produced in bioreactor. Vet. Immunol. Immunopathol. 198:44-53. <https://dx.doi.org/10.1016/j.vetimm.2018.02.010>

Davis D.S. \& Elzer P.H. 2002. Brucella vaccines in wildlife. Vet. Microbiol. 90(1/4):533-544. <https://dx.doi.org/10.1016/s0378-1135(02)00233-x> <PMid:12414169>

Dorneles E.M., Sriranganathan N. \& Lage A.P. 2015. Recent advances in Brucella abortus vaccines. Vet. Res. 46(1):76. <https://dx.doi.org/10.1186/ s13567-015-0199-7><PMid:26155935>

Elzer P.H., Enright F.M., Colby L., Hagius S.D., Walker J.V., Fatemi M.B., Kopec J.D., Beal Jr V.C. \& Schurig G.G. 1998. Protection against infection and abortion induced by virulent challenge exposure after oral vaccination of cattle with Brucella abortus strain RB51. Am. J. Vet. Res. 59(12):15751578. <PMid:9858409>

Elzer P.H., Smith J., Roffe T., Kreeger T., Edwards J. \& Davis D. 2002. Evaluation of Brucella abortus strain RB51 and strain 19 in pronghorn antelope. Ann. N. Y. Acad. Sci. 969:102-105. <https://dx.doi.org/10.1111/j.1749-6632.2002. tb04359.x> <PMid:12381572>

Estein S.M., Fiorentino M.A., Paolicchi F.A., Clausse M., Manazza J., Cassataro J., Giambartolomei G.H., Coria L.M., Zylberman V., Fossati C.A., Kjeken R. \& Goldbaum F.A. 2009. The polymeric antigen BLSOmp31 confers protection against Brucella ovis infection in rams. Vaccine 27(48):6704-6711.<https:// dx.doi.org/10.1016/j.vaccine.2009.08.097> <PMid:19748579>

Ficht T.A., Kahl-Mcdonagh M.M., Arenas-Gamboa A.M. \& Rice-Ficht A.C. 2009. Brucellosis: the case for live, attenuated vaccines. Vaccine 27(supl.4):D40-D43. <https://dx.doi.org/10.1016/j.vaccine.2009.08.058><PMid:19837284>

Fiorentino M.A., Campos E., Cravero S., Arese A., Paolicchi F., Campero C. \& Rossetti 0. 2008. Protection levels in vaccinated heifers with experimental vaccines Brucella abortus M1-luc and INTA 2. Vet. Microbiol. 132(3/4):302311.<https://dx.doi.org/10.1016/j.vetmic.2008.05.003><PMid:18565697>

Gándara B., Merino A., Rogel M. \& Martínez-Romero E. 2001. Limited genetic diversity of Brucella spp. J. Clin. Microbiol. 39(1):235-240. <https://dx.doi. org/10.1128/JCM.39.1.235-240.2001><PMid:11136777>

Godfroid J., Cloeckaert A., Liautard J.P., Kohler S., Fretin D., Walravens K., Garin-Bastuji B. \& Letesson J.J. 2005. From the discovery of the Malta fever's agent to the discovery of a marine mammal reservoir, brucellosis has continuously been a re-emerging zoonosis. Vet. Res. 36(3):313-326. <https://dx.doi.org/10.1051/vetres:2005003><PMid:15845228>

Gomez G., Adams L.G., Rice-Ficht A. \& Ficht T.A. 2013. Host-Brucella interactions and the Brucella genome as tools for subunit antigen discovery and immunization against brucellosis. Front. Cell. Infect. Microbiol. 3:17. <https://dx.doi.org/10.3389/fcimb.2013.00017> <PMid:23720712>

Gotuzzo E., Alarcon G.S., Bocanegra T.S., Carrillo C., Guerra J.C., Rolando I. \& Espinoza L.R. 1982. Articular involvement in human brucellosis: a retrospective analysis of 304 cases. Semin. Arthritis Rheum. 12(2):245-255. <https://dx.doi.org/10.1016/0049-0172(82)90064-6> <PMid:6101216>

Grégoire F., Mousset B., Hanrez D., Michaux C., Walravens K. \& Linden A. 2012. A serological and bacteriological survey of brucellosis in wild boar (Sus scrofa) in Belgium. BMC Vet. Res. 8:80.<https://dx.doi.org/10.1186/17466148-8-80> <PMid:22709889>

Grilló M.J., Marín C.M., Barberán M., de Miguel M.J., Laroucau K., Jacques I. \& Blasco J.M. 2009. Efficacy of bp26 and bp26/omp31 B. melitensis Rev.1 deletion mutants against Brucella ovis in rams. Vaccine 27(2):187-191. <https://dx.doi.org/10.1016/j.vaccine.2008.10.065><PMid:19007836>

Jacques I., Verger J.M., Laroucau K., Grayon M., Vizcaino N., Peix A., Cortade F., Carreras F. \& Guilloteau L.A. 2007. Immunological responses and protective efficacy against Brucella melitensis induced by bp26 and omp31 B. melitensis Rev.1 deletion mutants in sheep. Vaccine 25(5):794-805. <https://dx.doi. org/10.1016/j.vaccine.2006.09.051> <PMid:17070627>

Kahl-McDonagh M.M., Elzer P.H., Hagius S.D., Walker J.V., Perry Q.L., Seabury C.M., den Hartigh A.B., Tsolis R.M., Adams L.G., Davis D.S. \& Ficht T.A. 2006. Evaluation of novel Brucella melitensis unmarked deletion mutants for safety and efficacy in the goat model of brucellosis. Vaccine 24(24):5169-5177. <https://dx.doi.org/10.1016/j.vaccine.2006.04.005><PMid:16697090>

Ko J. \& Splitter G.A. 2003. Molecular host-pathogen interaction in brucellosis: current understanding and future approaches to vaccine development for mice and humans. Clin. Microbiol. Rev. 16(1):65-78. <https://dx.doi. org/10.1128/cmr.16.1.65-78.2003><PMid:12525425>

Marín C.M., Barberán M., Jiménez de Bagués M.P. \& Blasco J.M. 1990. Comparison of subcutaneous and conjunctival routes of Rev 1 vaccination for the prophylaxis of Brucella ovis infection in rams. Res. Vet. Sci. 48(2):209-215. <https://dx.doi.org/10.1016/S0034-5288(18)30992-5>

Marín C.M., Moreno E., Moriyon I., Díaz R. \& Blasco J.M. 1999. Performance of competitive and indirect enzyme-linked immunosorbent assays, gel immunoprecipitation with native hapten polysaccharide, and standard serological tests in diagnosis sheep brucellosis. Clin. Diagn. Lab. Immunol. 6(2):269-272. <PMid:10066666>

Marzetti S., Carranza C., Roncallo M., Escobar G.I. \& Lucero N.E. 2013. Recent trends in human Brucella canis infection. Comp. Immunol. Microbiol. Infect. Dis. 36(1):55-61. <https://dx.doi.org/10.1016/j.cimid.2012.09.002> $<$ PMid:23040615>

Nol P., Olsen S.C., Rhyan J.C., Sriranganathan N., McCollum M.P., Hennager S.G., Pavuk A.A., Sprino P.J., Boyle S.M., Berrier R.J. \& Salman M.D. 2016. Vaccination of elk (Cervus canadensis) with Brucella abortus strain RB51 overexpressing superoxide dismutase and glycosyltransferase genes does not induce adequate protection against experimental Brucella abortus challenge. Front. Cell. Infect. Microbiol. 6:1-10.<https://dx.doi.org/10.3389/ fcimb.2016.00010> <PMid:26904509>

Nomura A., Imaoka K., Imanishi H., Shimizu H., Nagura F., Maeda K., Tomino T., Fujita Y., Kimura M. \& Stein G. 2010. Human Brucella canis infections diagnosed by blood culture. Emerg. Infect. Dis. 16(7):1183-1185. <https:// dx.doi.org/10.3201/eid1607.090209> <PMid:20587207>

Olsen S.C. \& Stoffregen W.S. 2005. Essential role of vaccines in brucellosis control and eradication programs for livestock. Expert Rev. Vaccines 4(6):915928. <https://dx.doi.org/10.1586/14760584.4.6.915><PMid:16372886>

Olsen S.C., Bricker B., Palmer M.V., Jensen A.E. \& Cheville N.F. 1999. Responses of cattle to two dosages of Brucella abortus strain RB51: serology, clearance and efficacy. Res. Vet. Sci. 66(2):101-105. <https://dx.doi.org/10.1053/ rvsc.1998.0251> <PMid:10208887>

Olsen S.C., Mcgill J.L., Sacco R.E. \& Hennager S.G. 2015. Immune responses of bison and efficacy after booster vaccination with Brucella abortus strain RB51. Clin. Vaccine Immunol. 22(4):440-447.<https://dx.doi.org/10.1128/ CVI.00746-14> <PMid:25673305>

Pappas G., Akritidis N., Bosilkovski M. \& Tsianos E. 2005. Brucellosis. N. Engl. J. Med. 352(22):2325-2336. <https://dx.doi.org/10.1056/NEJMra050570> <PMid:15930423>

Paul S., Peddayelachagiri B.V., Nagaraj S., Kingston J.J. \& Batra H.V. 2018. Recombinant outer membrane protein $25 \mathrm{c}$ from Brucella abortus induces Th1 and Th2 mediated protection against Brucella abortus infection in mouse model. Mol. Immunol. 99:9-18. <https://dx.doi.org/10.1016/j. molimm.2018.04.002> <PMid:29649688>

Pendela S.V., Agrawal N., Mathew T., Vidyasagar S. \& Kudaravalli P. 2017. An Uncommon presentation of Brucella endocarditis masquerading as 
neurobrucellosis. J. Clin. Diagn. Res. 11(2):OD10-OD11. <https://dx.doi. org/10.7860/JCDR/2017/22979.9273><PMid:28384918>

Perkins S.D., Smither S.J. \& Atkins H.S. 2010. Towards a Brucella vaccine for humans. FEMS Microbiol. Rev. 34(3):379-394. <https://dx.doi. org/10.1111/j.1574-6976.2010.00211.x><PMid:20180858>

Plotkin S.A. 2010. Correlates of protection induced by vaccination. Clin. Vaccine Immunol. 17(7):1055-1065. <https://dx.doi.org/10.1128/ CVI.00131-10><PMid:20463105>

Poester F.P., Gonçalves V.S.P., Paixão T.A., Santos R.L., Olsen S.C., Schurig G.G. \& Lage A.P. 2006. Efficacy of strain RB51 vaccine in heifers against experimental brucellosis. Vaccine 24(25):5327-5334. <https://dx.doi. org/10.1016/j.vaccine.2006.04.020 > <PMid:16713034>

Poester F.P., Samartino L.E. \& Santos R.L. 2013. Pathogenesis and pathobiology of brucellosis in livestock. Rev. Sci. Tech. 32(1):105-115. <https://dx.doi. org/10.20506/rst.32.1.2193> <PMid:23837369>

Queipo-Ortuño M.I., Colmenero J.D., Muñoz N., Baeza G., Clavijo E. \& Morata P. 2006. Rapid diagnosis of Brucella epididymo-orchitis by real-time polymerase chain reaction assay in urine samples. J. Urol. 176(5):22902293. <https://dx.doi.org/10.1016/j.juro.2006.07.052><PMid:17070314>

Rajapakse C.N. 1995. Bacterial infections: osteoarticular brucellosis. Baillieres Clin. Rheumatol. 9(1):161-177. <https://dx.doi.org/10.1016/ s0950-3579(05)80153-0>

Rockx-Brouwer D., Chong A., Wehrly T.D., Child R., Crane D.D., Celli J. \& Bosio C.M. 2012. Low dose vaccination with attenuated Francisella tularensis strain SchuS4 mutants protects against tularemia independent of the route of vaccination. PLoS One 7:e37752. <https://dx.doi.org/10.1371/ journal.pone.0037752><PMid:22662210>

Saez D., Fernandez P., Rivera A., Andrews E. \& Oñate A. 2012. Oral immunization of mice with recombinant Lactococcus lactis expressing $\mathrm{Cu}$, $\mathrm{Zn}$ superoxide dismutase of Brucella abortus triggers protective immunity. Vaccine 30(7):1283-1290. <https://dx.doi.org/10.1016/j.vaccine.2011.12.088> <PMid:22222868>

Santos R.L., Martins T.M., Borges A.M. \& Paixão T.A. 2013. Economic losses due to bovine brucellosis in Brazil. Pesq. Vet. Bras. 33(6):759-764. <https:// dx.doi.org/10.1590/S0100-736X2013000600012>

Schurig G., Boyle S. \& Sriranganathan N. 1995. Brucella abortus vaccine strain RB51: a brief review. Arch. Med. Vet. 27:19-22.

Schurig G.G., Roop R.M. \& Bagchi T. 1991. Biological properties of RB51: a stable rough strain of Brucella abortus. Vet. Microbiol. 28(2):171-188. <https://dx.doi.org/10.1016/0378-1135(91)90091-s><PMid:1908158>

Schurig G.G., Sriranganathan N. \& Corbel M.J. 2002. Brucellosis vaccines: past, present and future. Vet. Microbiol. 90(1/4):479-496. <https://dx.doi. org/10.1016/s0378-1135(02)00255-9> <PMid:12414166>

Seder R.A. \& Hill A.V. 2000. Vaccines against intracellular infections requiring cellular immunity. Nature 406:793-798. <https://dx.doi. org/10.1038/35021239><PMid:10963610>

Silva A.P.C., Macêdo A.A., Costa L.F., Rocha C.E., Garcia L.N., Farias J.R., Gomes P.P.R., Teixeira G.C., Fonseca K.W.J., Maia A.R.F., Neves G.G., Romão E.L., Silva T.M.A., Mol J.P.S., Oliveira R.M., Araújo M.S.S., Nascimento E.F., MartinsFilho O.A., Brandão H.M., Paixão T.A. \& Santos R.L. 2015a. Encapsulated Brucella ovis lacking a putative ATP-binding cassette transporter $(\triangle a b c B A)$ protects against wild type Brucella ovis in rams. Plos One 10(8):e0136865. <https://dx.doi.org/10.1371/journal.pone.0136865><PMid:26317399>

Silva A.P.C., Macêdo A.A., Silva T.M.A., Ximenes L.C., Brandão H.M., Paixão T.A. \& Santos R.L. 2015b. Protection of an encapsulated live attenuated strain of Brucella ovis $(\triangle a b c \mathrm{BA})$ against experimental challenge in the murine model. Clin. Vaccine Immunol. 22(7):789-997. <https://dx.doi. org/10.1128/CVI.00191-15><PMid:25947146>
Silva T.M.A., Costa E.A., Paixão T.A., Tsolis R.M. \& Santos R.L. 2011a. Laboratory animal models for brucellosis research. J. Biomed. Biotechnol. 2011:1-9. <https://dx.doi.org/10.1155/2011/518323>

Silva T.M.A., Paixão T.A., Costa E.A., Xavier M.N., Sá J.C., Moustacas V.S., den Hartigh A.B., Carvalho Neta A.V., Oliveira S.C., Tsolis R. \& Santos R.L. 2011b. Putative ATP-binding cassette transporter is essential for Brucella ovis pathogenesis in mice. Infect. Immunit. 79(4):1706-1717. <https://doi. org/10.1128/IAI.01109-10><PMid:21300772>

Solera J., Martínez-Alfaro E. \& Espinosa A. 1998. Multivariate model for predicting relapse in human brucellosis. J. Infect. 36(1):85-92. <https:// dx.doi.org/10.1016/s0163-4453(98)93342-4><PMid:9515675>

Tabynov K., Sansyzbay A., Kydyrbayev Z., Yespembetov B., Ryskeldinova S., Zinina N., Assanzhanova N., Sultankulova K., Sandybayev N., Khairullin B., Kuznetsova I., Ferko B. \& Egorov A. 2014. Influenza viral vectors expressing the Brucella OMP16 or L7/L12 proteins as vaccines against B. abortus infection. Virol. J. 11:69. <https://dx.doi.org/10.1186/1743-422X-11-69> $<$ PMid:24716528>

Tabynov K., Yespembetov B., Matikhan N., Ryskeldinova S., Zinina N., Kydyrbayev Z., Assanzhanova N., Tabynov K., Renukaradhya G.J., Mukhitdinova G. \& Sansyzbay A. 2016. First evaluation of an influenza viral vector based Brucella abortus vaccine in sheep and goats: assessment of safety, immunogenicity and protective efficacy against Brucella melitensis infection. Vet. Microbiol. 197:15-20. <https://dx.doi.org/10.1016/j. vetmic.2016.11.001><PMid:27938677>

Titball R.W. 2008. Vaccines against intracellular bacterial pathogens. Drug Discov. Today 13(13/14):596-600. <https://dx.doi.org/10.1016/j. drudis.2008.04.010 > <PMid:18598915>

Tobias L., Schurig G.G. \& Cordes D.O. 1992. Comparative behaviour of Brucella abortus strains 19 and RB51 in the pregnant mouse. Res. Vet. Sci. 53(2):179-183. <https://dx.doi.org/10.1016/0034-5288(92)90107-d>

Todd T.E., Tibi O., Lin Y., Sayers S., Bronner D.N., Xiang Z. \& He Y. 2013. Metaanalysis of variables affecting mouse protection efficacy of whole organism Brucella vaccines and vaccine candidates. BMC Bioinformatics 14(supl.6):S3. <https://dx.doi.org/10.1186/1471-2105-14-S6-S3> <PMid:23735014>

Vemulapalli R., He Y., Sriranganathan N., Boyle S.M. \& Schurig G.G. 2002. Brucella abortus RB51: enhancing vaccine efficacy and developing multivalent vaccines. Vet. Microbiol. 90(1/4):521-532.<https://dx.doi.org/10.1016/ s0378-1135(02)00232-8><PMid:12414168>

Waag D.M., England M.J., Tammariello R.F., Byrne W.R., Gibbs P., Banfield C.M. \& Pitt M.L.M. 2002. Comparative efficacy and immunogenicity of $Q$ fever chloroform:methanol residue (CMR) and phase I cellular (Q-Vax) vaccines in cynomolgus monkeys challenged by aerosol. Vaccine 20(19/20):2623-2634 . <https://dx.doi.org/10.1016/s0264-410x(02)00176-7><PMid:12057622>

Wyckoff 3rd J.H., Howland J.L., Scott C.M., Smith R.A. \& Confer A.W. 2005. Recombinant bovine interleukin 2 enhances immunity and protection induced by Brucella abortus vaccines in cattle. Vet. Microbiol. 111(1/2):7787.<https://dx.doi.org/10.1016/j.vetmic.2005.09.004><PMid:16242273>

Xie J., Wang J., Li Z., Wang W., Pang Y. \& He Y. 2018. Ontology-Based metaanalysis of animal and human adverse events associated with licensed brucellosis vaccines. Front. Pharmacol. 9:503.<https://dx.doi.org/10.3389/ fphar.2018.00503><PMid:29867505>

Yang X., Skyberg J.A., Cao L., Clapp B., Thornburg T. \& Pascual D.W. 2013. Progress in Brucella vaccine development. Front. Biol. 8(1):60-77. <https:// dx.doi.org/10.1007/s11515-012-1196-0><PMid:23730309>

Young E.J. 1995. An overview of human brucellosis. Clin. Infect. Dis. 21(2):283289. <https://dx.doi.org/10.1093/clinids/21.2.283> <PMid:8562733> 